\title{
A STUDY TO EVALUATE CHANGE IN ATTITUDE OF MEDICAL STAFF TOWARDS ACCEPTANCE OF NABH IN KRISHNA HOSPITAL, KARAD
}

\author{
Sandhya Jagadale1, Kavita S. Kapurkar², Rohini Babar ${ }^{3}$
}

${ }^{1}$ Nurse Educator, Department of Administration and Management, Krishna Institute of Nursing Sciences, Karad, Satara, Maharashtra. ${ }^{2}$ Nurse Educator, Department of Administration and Management, Krishna Institute of Nursing Sciences, Karad, Satara, Maharashtra. ${ }^{3}$ Nursing Superintendent, Department of Administration and Management, Krishna Institute of Nursing Sciences, Karad, Satara, Maharashtra.

\section{ABSTRACT}

\section{BACKGROUND}

The standardisation comes if we adopt some sort of uniform accreditation. This study is conducted with the objectives to identify the attitude of medical staff on accreditation as well as their knowledge level on NABH standard.

\section{MATERIALS AND METHODS}

The study was conducted on 50 medical employees (doctors, nurses, HR staff, dietician and counsellor) of the hospital before and 6 months after the start of accreditation process in the Krishna Hospital, Karad. A questionnaire was used to collect the information about the attitude and knowledge of medical staff about NABH accreditation. Sample was collected by simple random method.

\section{RESULTS}

The study revealed that doctors and nurses including all other medical employees showed majority of positive attitude towards the acceptance of NABH after 6 months after the start of accreditation process in the Krishna Hospital, Karad.

\section{CONCLUSION}

This study concluded that employees showed positive attitude towards the implementation of NABH in Krishna Hospital, Karad.

\section{KEYWORDS}

Accreditation, Attitude, Doctors, Knowledge, NABH.

HOW TO CITE THIS ARTICLE: Jagadale S, Kapurkar KS, Babar R. A study to evaluate change in attitude of medical staff towards acceptance of NABH in Krishna Hospital, Karad. J.Evolution Med. Dent. Sci. 2016;5(84):6244-6248, D0I: 10.14260/jemds/2016/1412

\section{BACKGROUND}

Service quality has become a major concern for both the hospitals and the patients. The increase in competition coupled with the increased patients' perception of service quality makes it difficult for hospitals to provide services that meet patient satisfaction. Recognition of the importance of service quality is the need of the hour in order to provide better services to the patients. ${ }^{1}$

Since the quality is a crucial factor in health care, initiatives to address the quality of health care have become a worldwide phenomenon. A commitment to quality enhancement throughout the health care system involving all professional and service groups is essential to ensure that high quality in the health care is achieved, while minimising the inherent risks associated with modern health care delivery.

The focus of accreditation is on continuous improvement in organisational and clinical performance of health services and not just the achievement of certificate or award or

Financial or Other, Competing Interest: None.

Submission 15-09-2016, Peer Review 08-10-2016,

Acceptance 14-10-2016, Published 19-10-2016.

Corresponding Author:

Ms. Sandhya A. Jagadale,

Krishna Hospital \& Medical Research Centre,

Karad, Satara District,

Maharashtra.

E-mail: sandhyajagadale74@gmail.com

DOI: $10.14260 /$ jemds/2016/1412 merely assuring compliance with minimum acceptable standards.

Accreditation cannot be done without the cooperation of hospital staff especially the medical staff. The medical staff has direct involvement in patient care, and major standards of accreditation are related to them. Hence, there is a need to assess the attitude of medical staff on accreditation and to know the knowledge level of staff on accreditation standards. This brings out the need of the topic "Knowledge and Attitude of Medical Staff on NABH Accreditation".2

The demand for the latter has inevitably resulted in poor quality of medical care services with poor health outcomes. It is simple to compute the direct costs for various medical services; however, to compute the cost of quality is not only difficult but rather elusive, which has resulted in overdependence on subjective criteria. ${ }^{3}$ Various modalities like manpower ratios, infrastructure, medical technological capabilities, accreditation and quality assurance policies and mortality rates have been considered as quality indicators and have been used to evaluate the quality of health care services. The paper attempts to explore the implication of these quality indicators on the direct expenses incurred by patients while they seek health care services across India.

Economic growth has a positive effect on health of people by increasing their level of income (Gangadharan, 2008). 4 In the age of globalisation and liberalisation, India has achieved certain growth in its economy by increasing the standard of living of people which increases the consumers' expectation on quality in health care service (Pahuja and Vohra, 2012, Kumaraswamy, 2012). ${ }^{5}$ 


\section{Literature Survey}

In the globalised competitive hospital environment, service quality has been increasingly identified as the main factor in distinguishing between services and building competitive advantage. Unlike in the earlier days when hospitals were judged by the medical services they provided, they are now also judged on the quality of service they give, that is, personalised services rendered by courteous, caring and friendly staff. Hospitals will do even better if they could possibly combine high tech with a high touch. Service quality is designed to measure functional quality i.e. the manner in which the health care service is delivered to the patient. However, functional quality in a health care setting cannot be sustained without accurate diagnoses and procedures. Such technical quality is the focus of research that is being conducted by a number of health care professional organisations, including Joint Commission International (JCI), National Accreditation Board for Hospitals \& Health care Providers (NABH) and Quality Council of India (QCI), etc. For the long-run success of a health care organisation, both functional and technical quality has to be monitored and managed effectively (Babakus Emin \& W Glynn Mangold, 1992). Hence, the need to focus on the management aspects of hospitals has become more relevant than before. Measuring service quality as perceived by patients is one step to improve management of the hospitals. In this context, it is very essential to study the service quality in Indian hospitals. The present study is an attempt to develop an instrument for measuring perceived in-patent service quality in the context of Indian hospitals. ${ }^{6}$

The gap score for each statement is calculated as the perception score minus the expectation score. A positive gap score implies that expectations have been met or exceeded and a negative score implies that expectations are not being met. Gap scores can be analysed for individual statements and can be aggregated to give an overall gap score for each dimension. Early studies during 1980s concentrated on determining what service quality meant for customers and developing strategies to meet customer expectations (Parasuraman 1985). ${ }^{7}$

Service Quality, the well-documented service quality model i.e. SERVQUAL of Parasuraman et al (1985) has created a revolution in measuring the customers' perceptions towards the service delivered by the provider in various service sectors. Along with all service sectors, the model is also widely used for measuring service quality in health care including hospitals. According to SERVQUAL model, service quality occurs when expectations are met (or exceeded) (Parasuraman et al 1985). ${ }^{8}$ The changing health care environment with revised hospital accreditation guidelines have sharpened the clinical and administrative hospital staff's concern for evaluating the quality of care they provide. Clinicians now see accreditation standards as a framework by which organisational processes will be improved and their patients will receive better care. Physicians and administrators now must face the challenge of establishing comprehensive and vigorous systems of quality assurance and learn to avoid the traps that impede implementation of such systems. Quality assurance is a very simple process that deals with finding problems and fixing them.

A comprehensive definition of quality health care would be, "the optimal achievable result for each patient, the avoidance of physician-induced (iatrogenic) complications, and attention to patient and family needs in a manner that is both cost effective and reasonably documented."7

\section{MATERIALS AND METHODS}

\section{Research Design}

Study design was descriptive in nature.

\section{Research Setting}

Krishna Hospital - The information about the level of knowledge and attitude of medical staff about NABH was collected by questionnaire.

\section{Population}

The Population of the Study

Nurses, doctors and supportive staff. All the doctors, nurses, supportive staff of the organisation with experience more than 6 months were included in the study.

The tool and technique adopted for the data collection was questionnaire presented at beginning and 6 months of the start of the accreditation process. A questionnaire was prepared to collect the information on the level of knowledge and attitude of doctors and nurses and supportive staff on NABH accreditation.

\section{Sample Technique}

Simple random sample technique method.

\section{Tool}

Questionnaire to doctors and nurses.

\section{Section I \\ Demographic data and general information about the respondents.}

\section{Section II}

This section assessed the medical staff's attitude towards NABH accreditation and standards.

\section{Section III}

This section assessed the effects of accreditation on services.

\section{Section IV}

This section assessed the effects of accreditation of patient care.

\section{Section V}

This section assessed the attitude of medical staff towards infection control practices.

\section{Section VI}

This section assessed the HR management.

The investigator obtained the NABH standards from the guide book of NABH standards. Questionnaires were prepared based on that material and distributed among the sample groups of doctors and nursing staff to get feedback about the attitude and knowledge on NABH accreditation.

\section{Inclusion Criteria}

Doctors and nurses who had working experience for at least 6 months in the particular hospital were only included in the sample group. 
Exclusion Criteria

Staff that had less than 6 months experience.

\section{Data Analysis}

Statistical calculation was done using SPSS 15 with the percentage, mean and standard deviation as a measure for descriptive analysis.

\section{RESULTS}

\begin{tabular}{|c|c|c|c|c|c|c|}
\hline \multirow{2}{*}{ Particulars } & \multicolumn{3}{|c|}{$1^{\text {st }}$ Assessment } & \multicolumn{3}{c|}{ 2nd Assessment $^{\text {A }}$} \\
\cline { 2 - 7 } & SA n (\%) & A n (\%) & D n (\%) & SA n (\%) & A (\%) & D n (\%) \\
\hline Name sake & $11(20)$ & $21(38.18)$ & $23(41.81)$ & $10(16.6)$ & $38(63.3)$ & $12(20)$ \\
\hline Patient & $33(60)$ & $22(40)$ & - & $34(61.81)$ & $18(32.72)$ & - \\
\hline $\begin{array}{c}\text { Benefit for health } \\
\text { care professionals }\end{array}$ & $29(52.72)$ & $26(47.27)$ & - & $37(65.45)$ & $18(32.72)$ & - \\
\hline $\begin{array}{c}\text { Benefit for the } \\
\text { organisation }\end{array}$ & $27(49)$ & $24(43.63)$ & $4(7.27)$ & $36(45)$ & $18(32.72)$ & $1(1.81)$ \\
\hline \multicolumn{7}{|c|}{ Table 1. Need for Accreditation } \\
\hline
\end{tabular}

SA: Strongly Agree, A: Agree, D: Disagree.

On the first assessment, $20 \%$ thought it was name sake, $60 \%$ considered it to be beneficial to patient and $52.72 \%$ would help the health care professionals, $49 \%$ considered it as a benefit for the organisation, whereas post exposure these figures changed to $16.6 \%, 61.81 \%, 65.45 \%, 45 \%$.

\begin{tabular}{|c|c|c|c|c|c|c|}
\hline \multirow{2}{*}{ Particulars } & \multicolumn{3}{|c|}{ 1st Assessment } & \multicolumn{3}{c|}{ 2nd Assessment } \\
\cline { 2 - 7 } & SA n (\%) & A n (\%) & D n (\%) & SA n (\%) & A n (\%) & D n (\%) \\
\hline Improve the quality of service & $25(45.45)$ & $30(54.5)$ & - & $34(61.81)$ & $21(38.18)$ & - \\
\hline $\begin{array}{c}\text { Improves the outlook about the } \\
\text { services to be rendered }\end{array}$ & $19(34.54)$ & $34(61.81)$ & $1(1.81)$ & $19(34.54)$ & $35(63.63)$ & $1(1.81)$ \\
\hline Makes the work systematic & $22(40)$ & $32(58.18)$ & $1(1.81)$ & $35(63.63)$ & $20(36.36)$ & - \\
\hline Improves image for the hospital & $22(40)$ & $31(56.36)$ & $2(3.63)$ & $33(60)$ & $18(32.72)$ & $4(7.27)$ \\
\hline $\begin{array}{c}\text { Helps the health care professionals to } \\
\text { update themselves }\end{array}$ & $21(38.18)$ & $34(61.81)$ & $1(1.81)$ & $38(69.09)$ & $26(47.27)$ & $1(1.81)$ \\
\hline \multicolumn{3}{|c|}{ Table 2. Positive Effect } \\
\hline
\end{tabular}

SA: Strongly Agree, A: Agree, D: Disagree

On the first assessment, $45.45 \%$ considered that accreditation improves the quality of service, $34.54 \%$ considered it is for better outlook about services, $40 \%$ thought that it makes the work systematic, $40 \%$ thought that it would help the health care professionals whereas post-exposure $30 \%$ thought it provides good image to the hospital and these figures changed to $61.81 \%$, $34.54 \%, 63.63 \%, 60 \%, 69.09 \%$ (Table 2).

\begin{tabular}{|c|c|c|c|c|c|c|}
\hline \multirow{2}{*}{ Particulars } & \multicolumn{3}{|c|}{ 1st Assessment } & \multicolumn{3}{c|}{ 2n Assessment $^{\text {nd }}$} \\
\cline { 2 - 7 } & SA n (\%) & A n (\%) & D n (\%) & SA n (\%) & A n (\%) & D n (\%) \\
\hline Increases the workload of the staff & $23(58.18)$ & $22(40)$ & $10(18.18)$ & $15(27.27)$ & $25(45.45)$ & $15(27.27)$ \\
\hline Increases the documentation process & $10(18.18)$ & $35(63.63)$ & $10(18.18)$ & $12(21.81)$ & $9(16.36)$ & $34(61.81)$ \\
\hline $\begin{array}{c}\text { Unnecessary management } \\
\text { intervention in our work }\end{array}$ & $3(5.45)$ & $15(27.27)$ & $37(67.27)$ & $3(5.45)$ & $16(29.09)$ & $36(65.45)$ \\
\hline $\begin{array}{c}\text { High chance of legal action by } \\
\text { patients against us }\end{array}$ & $10(18.18)$ & $25(45.45)$ & $20(3.63)$ & $5(9.09)$ & $18(32.72)$ & $32(58.18)$ \\
\hline Increases the stress level of the staff & $5(9.09)$ & $27(49.09)$ & $23(41.81)$ & $12(21.81)$ & $22(40)$ & $21(38.18)$ \\
\hline Affects the productivity of the staff & $4(7.27)$ & $34(61.81)$ & $17(39.90)$ & $13(26.63)$ & $18(32.72)$ & $24(43.63)$ \\
\hline Decreases job satisfaction level & $1(1.81)$ & $15(27.27)$ & $39(70.90)$ & $6(10.90)$ & $10(18.18)$ & $39(70.90)$ \\
\hline \multicolumn{3}{|c|}{ Table 3. Negative Effect } & \\
\hline
\end{tabular}

SA: Strongly Agree, A: Agree, D: Disagree.

On the first assessment, 58.18\% respondents found that accreditation increases workload of the staff, $18.18 \%$ found it increases the documentation process, $5.45 \%$ found it is an unnecessary management intervention, $18.18 \%$ thought with accreditation there is a high chance for legal action by patient, $9.09 \%$ considered it increases the stress level of the staff, $7.27 \%$ feel it affects the productivity of the staff, and 1.81\% considered it decreases job satisfaction level, whereas post exposure these figures are $27.27 \%, 21.81 \%, 5.45 \%, 9.09 \%, 21.81 \%, 26.63 \%, 10.90 \%$ considered it decreases job satisfaction (Table 3). 


\begin{tabular}{|c|c|c|c|c|}
\hline \multirow[b]{2}{*}{ Particulars } & \multicolumn{2}{|c|}{ 1st Assessment } & \multicolumn{2}{|c|}{ 2nd Assessment $^{\text {nd }}$} \\
\hline & $\begin{array}{l}\text { Yes - } \\
\text { N (\%) }\end{array}$ & $\begin{array}{c}\text { No- } \\
\text { N (\%) }\end{array}$ & $\begin{array}{l}\text { Yes - } \\
\text { N (\%) }\end{array}$ & $\begin{array}{c}\text { No- } \\
\text { N (\%) }\end{array}$ \\
\hline $\begin{array}{l}\text { The initial assessment for inpatients should be done and documented } \\
\text { within specified time frame }\end{array}$ & $20(36.36)$ & $35(63.63)$ & $53(96.35)$ & $2(3.63)$ \\
\hline Every medical renewal entry is dated and timed & $26(47.27)$ & $29(52.72)$ & $53(96.35)$ & $2(3.63)$ \\
\hline $\begin{array}{l}\text { All medical notes have to be named and signed by the clinician } \\
\text { in-charge of the patients within } 24 \mathrm{hrs} \text {. }\end{array}$ & $34(61.81)$ & $21(38.18)$ & $54(98.18)$ & $1(1.18)$ \\
\hline $\begin{array}{l}\text { The care plan should be countersigned by the clinician } \\
\text { in-charge of the patients within } 24 \mathrm{hrs} \text {. }\end{array}$ & $23(41.81)$ & $32(58.18)$ & $53(96.29)$ & $2(3.63)$ \\
\hline Better results & $28(50.90)$ & $27(48.08)$ & $55(100)$ & - \\
\hline Decreases medication error & $28(50.90)$ & $27(48.08)$ & $51(92.71)$ & $4(7.27)$ \\
\hline Improves patient's rights & $30(54.54)$ & $25(45.45)$ & $50(100)$ & - \\
\hline Improves patient's satisfaction & $32(58.18)$ & $23(41.81)$ & $50(100)$ & - \\
\hline
\end{tabular}

Table 4. Medical Error

After 6 months, 96.35\% respondents considered that the initial assessment for patients must be documented within time frame and considered that every medical renewal entry should be dated and timed. $98.18 \%$ respondents agreed that medical record should be named and signed. $96.29 \%$ wanted care plan to be countersigned by the clinician in-charge of the patient within 24 hours. $92.71 \%$ felt it decreases medical error and $100 \%$ felt it improves patient's rights and satisfaction compared to pre-exposure (Table. 4).

\begin{tabular}{|c|c|c|c|c|}
\hline \multirow{2}{*}{ Particulars } & \multicolumn{2}{|c|}{$1^{\text {st }}$ Assessment } & \multicolumn{2}{|c|}{ 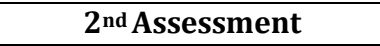 } \\
\hline & Yes - n (\%) & No - n (\%) & Yes - n (\%) & No - n (\%) \\
\hline Use proper hand washing facilities in the critical area & $31(56.36)$ & $24(43.63)$ & $44(80)$ & $11(20)$ \\
\hline Use the isolation/barrier nursing facilities & $35(63.63)$ & $20(36.36)$ & $54(98.17)$ & $1(1.81)$ \\
\hline Use gloves, masks during procedure & $44(80)$ & $11(20)$ & $46(83.63)$ & $9(16.36)$ \\
\hline $\begin{array}{l}\text { Awareness about the sterilisation practices in the } \\
\text { hospital }\end{array}$ & $39(70.90)$ & $16(20.09)$ & $41(74.54)$ & $14(25.45)$ \\
\hline $\begin{array}{l}\text { Awareness about the biomedical waste } \\
\text { management processes in the hospital }\end{array}$ & $35(63.63)$ & $20(36.36)$ & $45(81.81)$ & $10(18.18)$ \\
\hline $\begin{array}{l}\text { Inform the management about the injuries } \\
\text { such as needle prick injuries }\end{array}$ & $43(78.18)$ & $12(21.81)$ & $54(98.18)$ & $1(1.81)$ \\
\hline $\begin{array}{l}\text { Aware of the infection control practices to } \\
\text { be followed in ICUs and high dependence units }\end{array}$ & $38(69.09)$ & $17(30.33)$ & $55(100)$ & - \\
\hline
\end{tabular}

Table 5. Infection Control Practices

Attitude towards infection control policies, morbidity and mortality outcomes improved due to better implementation of injection control policies with knowledge as majority of the staff used better techniques. (Table 5)

\begin{tabular}{|c|c|c|c|c|}
\hline \multirow{2}{*}{ Particulars } & \multicolumn{2}{|c|}{ 1st Assessment $^{\text {st }}$} & \multicolumn{2}{c|}{ 2 $^{\text {nd }}$ Assessment } \\
\cline { 2 - 5 } & Yes - n (\%) & No - n (\%) & Yes - n (\%) & No - n (\%) \\
\hline $\begin{array}{c}\text { Rights of staff - better taken care by } \\
\text { organisation }\end{array}$ & $28(50.30)$ & $27(49.09)$ & $28(50.90)$ & $27(49.09)$ \\
\hline $\begin{array}{c}\text { Decreases risk of disease transmission } \\
\text { Better work condition }\end{array}$ & $26(47.27)$ & $22(40)$ & $30(54.54)$ & $25(45.45)$ \\
\hline Better financial status & $33(60)$ & $22(40)$ & $30(54.54)$ & $25(45.45)$ \\
\hline \multicolumn{2}{|c}{ Table 6. HR Management } \\
\hline
\end{tabular}

Majority employees agreed that NABH policy improves job satisfaction, feeling of security, better work conditions. (Table 6.)

\section{DISCUSSION}

The present study was done to find out the level of attitude and knowledge of hospital employees on NABH accreditation in Krishna Hospital which is on the way to NABH and study proved that nurses and doctors had a positive attitude towards accreditation after 6 months.

A similar study, "employee attitude towards the implementation of quality management system with special reference" conducted in Coimbatore K. G. Hospital by P. Sivasankar, concluded that employees had positive attitude towards the implementation of quality management system.vol.2 No.4 Oct 2013.10

The knowledge level among medical staff on NABH standards improved and a better compliant and harmonious working atmosphere was created between doctors and nurses.

\section{CONCLUSION}

This study concluded that employees showed positive attitude towards the implementation of NABH in Krishna 
Hospital, Karad. The sound knowledge and a positive attitude towards NABH accreditation among the medical staff are very important and the same can be accomplished with proper training and good hospital environment.

\section{Future Scope \\ Nursing Implication}

The findings of this study have implications for nursing practice, nursing education, nursing administration and nursing research.

\section{Nursing Practice}

The knowledge and practice of NABH accreditation and standard guidelines need to be provided to all nursing personnel and can be continued in the hospital.

\section{Nursing Administration}

The finding of the study will help the nurse administrator to organise more workshops, panel discussion, short-term refresher courses and health education programs for nurses.

\section{Nursing Research}

Research suggests that accreditation of a hospital is a good way to provide standardisation in treatment.

\section{REFERENCES}

1. Johnston R. The zone of tolerance: exploring the relationship between service transactions and satisfaction with the overall service. International Journal of Service Industry Management 1995;6(2):4661.
2. Jyothi G, Bidhan D. Developing national accreditation systems: needs, challenges and future directions. Express Health Care Management 2005.

3. Shah U. Quality and cost of health care: an Indian perspective. An assessment of direct cost of quality across hospitals in India. Management in health 2011:15(3).

4. Gangadharan K. Policy reforms and health care system in Kerala: constraints and options. Journal of Health and Development 2008;4(1-4):195-208.

5. Itumalla R. Information technology and service quality in health care: an empirical study of private hospital in India. International Journal of Innovation, Management and Technology 2012;3(4):433-6.

6. Itumalla R, Acharyulu GVRK, RajaShekhar B, et al. Development of hospital qual: a service quality scale for measuring in-patient services in hospital. Operations and Supply Chain Management 2014;7(2):54-63.

7. Berry LL, Zeithaml VA, Parasuraman A. Quality counts in services, too. Business Horizons 1985; 28(3):44-52.

8. Agarwal R. Guidelines for quality accreditation in Hospitals. www.qualitydigest.com/inside/health- carearticle/guideline-quality-accreditation-hospitals.

9. Sivasankar P. Employee's attitude towards the implementation of quality management system with special reference conducted in K.G. Hospital, Coimbatore. Int J Mgmt Res \& Bus Strat 2013;2(4):122-8. 